\title{
Effect of Dietary 5-Hydroxy-L-Tryptophan for Prevention of Scoliosis in Tryptophan-Deficient Chum Salmon Fry
}

\author{
Toshio Akiyama, ${ }^{* 1}$ Hideaki Kabuto, ${ }^{* 2}$ Midori Hiramatsu, ${ }^{* 2}$ \\ Takeshi Murai,*1 and Katsuyoshi Mori*1 \\ (Received June 11, 1988)
}

\begin{abstract}
Tryptophan (Trp)-deficient diets (Trp $50 \mathrm{mg} / 100 \mathrm{~g}$ diet) supplemented with graded levels of 5-hydroxy-L-tryptophan (5-HTP; 0.1, 1, $10 \& 100 \mathrm{mg} / 100 \mathrm{~g}$ diet) were fed to chum salmon fry Oncorhynchus keta to clarify whether 5-HTP, the precursor of serotonin (5-HT), prevents scoliosis caused by Trp deficiency and affects the levels of neurotransmitters in fish brain. The administration of the dose of less than $10 \mathrm{mg}$ of $5-\mathrm{HTP} / 100 \mathrm{~g}$ diet caused scoliosis in $62-65 \%$ of fish atfer 4 weekrearing, whereas the increase in dietary level of $100 \mathrm{mg}$ reduced this value to $1.7 \% .5-\mathrm{HT}$ and 5-hydroxyindoleacetic acid (5-HIAA) contents in the brain of the fish fed Trp-deficient diet containing $100 \mathrm{mg}$ 5-HTP/100 $\mathrm{g}$ diet as well as those of Trp-sufficient diet (Trp $290 \mathrm{mg} / 100 \mathrm{~g}$ diet) were higher than those of the other dietary groups. The brain norepinephrine (NE) contents showed a tendency to rise as the supplemental level of 5-HTP increased. These results clearly indicate that the oral administration of 5-HTP up to the level of $100 \mathrm{mg} / 100 \mathrm{~g} \mathrm{dict} \mathrm{or} 40 \mathrm{mg} / \mathrm{kg}$ body weight/ day can almost completely prevent occurrence of scoliosis. Incidence of scoliosis in the fish fed Trp-free diet (Trp 0\%) was only 15\% even though brain 5-HT content of this group was in the same range as those fed Trp-deficient diet containing supplemental 5 -HTP up to $10 \mathrm{mg} / 100 \mathrm{~g}$ diet. However, the brain NE and dopamine contents of the former were almost the same as those fed Trp-sufficient diet. These findings suggest that catecholamine may be also involved in an occurrence of scoliosis and that there is a considerable physiological difference between complete absence of Trp and intake of small quantity of Trp.
\end{abstract}

In the previous paper, we have reported that the occurrence of scoliosis caused by Tryptophan (Trp) deficiency may be related to the depletion of serotonin (5-HT) in the body, probably in the central nervous system., ${ }^{1,2)}$ and that the orla administration of 5-hydroxy-L-tryptophan (5-HTP; $130 \mathrm{mg} / 100 \mathrm{~g}$ diet) completely inhibited the occurrence of scoliosis in Trp-deficient chum salmon fry. ${ }^{2)}$ In this study, along with reconfirming the effect of 5-HTP supplementation for prevention of scoliosis, the experiment was conducted to also clarify the influences of 5-HTP to the substances in brain, especially 5-HT and catecholamines which act as neurotransmitter competitively with 5-HT.

It is also known that incidence of scoliosis is higher in the fish fed Trp-deficient diet containing low level of Trp than that fed the diet containing no $\operatorname{Trp}$ in rainbow trout ${ }^{32}$ and coho salmon. ${ }^{* 3}$
Trp-free diet was included in this trial to confirm that this phenomenon occurs also in chum salmon.

\section{Materials and Methods}

The experimental diets were formulated from purified ingredients as shown in Table 1 , which are basically the same compositions as those of the previous papers..$^{1,2,8)}$ The ingredients were processed to the diets in the same manner as reported previously. ${ }^{72}$ Crude protein level was adjusted to approximately $40 \%$ using crystalline amino acids or casein. The $\mathrm{pH}$ of test diet was neutralized with $\mathrm{NaOH}$ solution. Diet 1 was Trp-free diet containing no Trp source. Diets 2-6 were Trp-deficient diets containing $50 \mathrm{mg}$ $\operatorname{Trp} / 100 \mathrm{~g}$ diet which came from casein. For diets $3-6,0.1,1,10$ and $100 \mathrm{mg}$ 5-HTP/100 g diet were supplemented, respectively. Diet 7 was

*1 Fish Nutrition Division, National Research Institute of Aquaculture, Nansei, Mie 516-01, Japan (秋山敏男，村井武四，森 勝義：水産庁美殖研究所栄羡代謝部).

*2 Department of Neurochemistry, Institute for Neurobiology, Okayama University Medical School, Shikata, Okayama 700, Japan (加太英明, 平松 緑: 阔山大学医学部媨代謝研究施設機能生化学部門).

*3 H. Ogata and S. Arai: The abstract papers of the Autumn Meeting of Japan. Soc. Sci. Fish., Sci. p. 44 (1981). 
Table 1. Percentage compositions of test diets

\begin{tabular}{|c|c|c|c|c|c|c|c|}
\hline $\begin{array}{c}\text { Diet no. } \\
\text { Trp \% in diet } \\
\end{array}$ & $\begin{array}{l}1 \\
0\end{array}$ & $\begin{array}{l}2 \\
0.05 \\
\end{array}$ & $\begin{array}{l}3 \\
0.05\end{array}$ & $\begin{array}{l}4 \\
0.05 \\
\end{array}$ & $\begin{array}{l}5 \\
0.05 \\
\end{array}$ & $\begin{array}{l}6 \\
0.05 \\
\end{array}$ & $\begin{array}{l}7 \\
0.29 \\
\end{array}$ \\
\hline \multicolumn{8}{|l|}{ Ingredient } \\
\hline Vitamin-free casein*1 & - & 5 & 5 & 5 & 5 & 5 & 5 \\
\hline Fish oil $* 2$ & 12 & 12 & 12 & 12 & 12 & 12 & 12 \\
\hline Dextrin & 20 & 20 & 20 & 20 & 20 & 20 & 20 \\
\hline Vitamin mix ${ }^{* 3}$ & 4.5 & 4.5 & 4.5 & 4.5 & 4.5 & 4.5 & 4.5 \\
\hline Mineral mix*4 & 4 & 4 & 4 & 4 & 4 & 4 & 4 \\
\hline $\mathrm{CMC}^{* 5}$ & 8 & 8 & 8 & 8 & 8 & 8 & 8 \\
\hline Cellulose & 5.83 & 6.24 & 6.24 & 6.24 & 6.24 & 6.22 & 6.21 \\
\hline $5-\mathrm{HTP} * \mathrm{\theta}$ & - & - & 0.0001 & 0.001 & 0.01 & 0.1 & - \\
\hline L-Tryptophan & - & - & - & 一 & - & - & 0.24 \\
\hline L-Alanine & 7.93 & 7.75 & 7.75 & 7.75 & 7.74 & 7.67 & 7.54 \\
\hline Amino acid mix & $37.74^{* 7}$ & $32.51^{* 8}$ & $32.51^{* 8}$ & $32.51 * 8$ & $32.51^{* 8}$ & $32.51^{* 8}$ & $32.51^{* 8}$ \\
\hline
\end{tabular}

*1 (Lot no. 2034) Product of United State Biochemical Corporation.

*2 Pollack liver oil: Product of Riken Vitamin Company, Ltd.

*8 The permix reported by National Research Council.4); partly modified as follows. (mg/100 $\mathrm{g}$ diet): Thiamin HCl 5, Ribofiavin 20, Pyridoxine $\mathrm{HCl} \mathrm{5,} \mathrm{Choline} \mathrm{chloride} \mathrm{500,} \mathrm{Nicotinic} \mathrm{acid} \mathrm{75,} \mathrm{Ca-pantothenate} \mathrm{50,} \mathrm{Inositiol} \mathrm{200,} \mathrm{Biotin} \mathrm{0.5,} \mathrm{Folic} \mathrm{acid} \mathrm{1.5,} \mathrm{As-}$ corbic acid 100, Menadione 4, Alpha-tocopherol 40, Vitamin $B_{12}$ 0.01, Activated 7-dehydro-cholesterol 0.005, Beta-carotene 2.

*4 U.S.P. XII Salt mixture no. 2 with trace elements. 5 )

*5 Carboxymethylcellulose-Na.

*6 S-Hydroxy-L-Tryptophan: SIGMA Chemical Company.

*7 (g/100 g diet): L-Arginine 2.40, L-Histidine 1.40, L-Isoleucine 1.60, L-Leucine 2.92, L-Lysine HCl 4.30, L-Methionine 1.20, L-Cystine 0.48 , L-Pbenylalanine 1.68, L-Tyrosine 1.40, L-L-Threonine 1.88, L-Valine 1.84, L-Aspartic acid 3.92, L-Glutamic acid 6.28, LGlycine 2.72, L-Proline 1.92, L-Serine 1.80: product of Ajinomoto Company, Ltd.

*B (g/100 g diet) : L-Arginine 2.23, L-Histidine 1.27, L-Isoleucine 1.37, L-Leucine 2.48, L-Lysine HCl 3.83, L-Methionine 1.08, L-Cystine 0.45, L-Phenylalanine 1.45, L-Tyrosine 1.14, L-Threonine 1.64, L-Valine 1.56, L-Aspartic acid 3.51, L-Glutamic acid 5.00, L-Glycine 2.63, L-Proline 1.41, L-Serine 1.46: product of Ajinomoto Company, Ltd.

supplemented with crystalline L-Trp up to $290 \mathrm{mg}$ $\operatorname{Trp} / 100 \mathrm{~g}$ diet in total, which is the quantitative Trp requirement of chum salmon fry. ${ }^{\text {e) }}$

Chum salmon eggs were transferred from Chitose Branch of Hokkaido Salmon Hatchery and hatched out at the laboratory in the freshwater station of our institute. Preparation for the experimental fish, feeding method and the other experimental conditions were the same as those reported previously.") When the fry attained to an average body weight of $2.0-2.2 \mathrm{~g}$ (92 days old after hatching), a feeding experiment was started and lasted for 4 weeks supplying well water $(1.4-1.8 \mathrm{l} / \mathrm{min})$ at $15^{\circ} \mathrm{C}$. At the end of experiment, incidence of scoliosis was checked and a certain number of fish were sacrificed from each dietary group for analysis of monoamines or amino acids in the brain. Brain samples, which were removed from head soon after killing by decapitation, were immediately frozen on dry-ice and then stored at $-80^{\circ} \mathrm{C}$ until analyzed.

For 5-HT and 5-hydroxyindoleacetic acid (5HIAA) analyses, 3 pooled samples (5-8 fish/ sample) were taken from each dietary group. Extraction of 5-HT and 5-HIAA from each sample was conducted by the method of Curzon and
Green. ${ }^{8)}$ The conditions of high performance liquid chromatography (Jasco MC-540) for 5-HT analysis were as follows: the column, SS-ODS246250 ; solvent, $5 \%$ acetonitrile $/ 0.1 \mathrm{M}$ phosphate buffer (pH 3.0). The native fluorescence of 5-HT in aqueous phase of extract was measured at Ex $280 \mathrm{~nm}$ and $\mathrm{Em} 313 \mathrm{~nm}$ by using Jasco Spectrofluoro monitor FP-540 as a detector. For determination of 5-HIAA, whole volume of organic phase remaining after the extraction of 5-HT was transferred to centrifuge tube containing $0.6 \mathrm{~m} l$ of $0.5 \mathrm{M}$ phosphate buffer and then it was shaken for $10 \mathrm{~min}$, and centrifuged at $3000 \mathrm{rpm}$ for $5 \mathrm{~min}$. Then, $0.04 \mathrm{~m} l$ of $0.1 \%$ L-cystein, $0.8 \mathrm{~m} l$ of $\mathrm{HCl}$ conc., $0.04 \mathrm{ml}$ of $0.1 \% O$-phthalaldehyde/methyl alcohol and $0.04 \mathrm{ml}$ of $0.02 \%$ sodium periodate solution were added to $0.4 \mathrm{~m} l$ of aqueous phase and the mixture was placed in boiling water for $10 \mathrm{~min}$. The formed fluorescence was measured by HITACHI Fluorescence Spectrophotometer 650-10(S) at Ex $360 \mathrm{~nm}$ and Em $470 \mathrm{~nm}$. Catecholamines were analyzed as follows: to one brain, $0.1 \mathrm{~m} l$ of $0.1 \mathrm{M}$ ethylenediaminetetraacetic acid, disodium salt, $0.1 \mathrm{ml}$ of $0.1 \mathrm{M}$ sodium bisulfite, $2.7 \mathrm{ml}$ of $0.05 \mathrm{M}$ perchloric acid and a proper quantity of 3,4-dihydroxybenzylamine were added. 
Those mixtures were homogenized and centrifuged at $8000 \mathrm{rpm}$ for $15 \mathrm{~min}$. To the supernatant, $30 \mathrm{mg}$ of activated alumina and $3 \mathrm{ml}$ of $1 \mathrm{M}$ Tris $\mathrm{HCl}$ buffer ( $\mathrm{pH} \mathrm{8.6)}$ were added. The mixture was shaken for $15 \mathrm{~min}$ and then the supernatant was removed. The remaining alumina was washed three times with $3 \mathrm{~m} l$ of distilled water and the water used for washing was then freeze-dried. To the remaining solid, $0.5 \mathrm{~m} l$ of $0.1 \mathrm{~N} \mathrm{HCl}$ was added and the mixture was shaken and centrifuged at $5000 \mathrm{rpm}$ for $5 \mathrm{~min}$. The supernatant was separated by Yanaco HPLC L-4000 W (Column: YANAPAC ODS-A), and norepinephrine (NE) and dopamine (DA) were simultaneously measured by Yanaco Twin Electrode Voltammetry Detector VMD-501. For the determination of amino acids, 2 pooled samples ( 6 fish/sample) per each dietary group were homogenized after adding $3 \mathrm{~m} l$ of $15 \%$ sulfosalicylic acid. The mixture was shaken for $10 \mathrm{~min}$ and centrifuged at $10000 \mathrm{rpm}$ for $15 \mathrm{~min}$. The supernatant was immediately frozen at $-80^{\circ} \mathrm{C}$ until analysis. After $0.15 \mathrm{~m} l$ of aliquot from the supernatant was diluted by $0.3 \mathrm{ml}$ of Li-S buffer solution (produced by BECKMAN), amino acids were measured by BECKMAN System 6300 High Performance Amino Acid Analyzer.

Data on growth, feed efficiency, feed consumption, incidence of scoliosis and levels of monoamines and amino acids were analyzed for significance $(p<0.05)$ using Duncan's multiple-range test. ${ }^{8)}$

\section{Results and Discussion}

The results in our feeding trial were shown in
Table 2. The growth, feed efficiency and feed consumption of the fish fed Trp-sufficient diet containing the requisite level of $\operatorname{Trp}$ (Diet 7; control) were higher than those of the remaining dietary groups. Although the feed consumption in the group fed Trp free-diet (Diet 1) was as the same level as those of the groups fed Trp-deficient diet (Diets 2-6), almost no growth response with the subsequent extremely low feed efficiency was observed. The value of feed efficiency in each group fed Trp-deficient diet was intermediate between those of groups fed Trp-free and Trpsufficient diet, and the fish fed Trp-deficient diet grew up to one-third of the control. Among the fish fed Trp-deficient diets (Diets 2-6), essentially no influences of 5-HTP supplementation were detected on the growth, feed efficiency and feed consumption. There were no mortalities in all groups throughout the 4-week feeding experiment.

In the previous paper, no scoliosis was observed in the fish when fed Trp-deficient diet containing $130 \mathrm{mg} 5-\mathrm{HTP} / 100 \mathrm{~g}$ diet. $^{2)}$ In this trial either, no scoliotic fish was found in the control, and scoliosis was noted only in $1.7 \%$ of the fish fed Trp-deficient diet supplemented with $100 \mathrm{mg} \mathrm{5-}$ HTP/100 $\mathrm{g}$ diet (Diet 6) as shown in Table 2. The levels of brain indoleamine such as 5-HT and 5-HIAA of 5-HT metabolite in the fish fed Diet 6 were as high as those in the fish fed Trpsufficient diet (Table 3). On the other hand, scoliosis was observed in $62-65 \%$ of the fish fed the Trp-deficient diets containing 0-10 mg 5HTP $/ 100 \mathrm{~g}$ diet (Diets 2-5) and the brain 5-HT level was significantly lower than that of the control. NE contents of the fish fed Trp-deficient diet (Diets 2-6) became higher and gradually

Table 2. Effects of dietary 5-hydroxy-L-tryptophan (5-HTP) on the growth, feed efficiency, feed consumption and incidence of scoliotic fish of chum salmon fry*1

\begin{tabular}{|c|c|c|c|c|c|c|c|}
\hline Diet no. & $\begin{array}{l}\text { Trp \% } \\
\text { in diet }\end{array}$ & $\begin{array}{c}\text { Dietary } \\
\text { treatment }\end{array}$ & $\begin{array}{c}\text { Initial } \\
\text { mean } \\
\text { body } \\
\text { weight } \\
(\mathrm{g})\end{array}$ & $\begin{array}{c}\text { Weight } \\
\text { gain } \\
(\%)\end{array}$ & $\begin{array}{l}\text { Feed }{ }^{* 2} \\
\text { efficiency } \\
(\%)\end{array}$ & $\begin{array}{l}\text { Daily } \\
\text { Feed } \\
\text { consump- } \\
\text { tion } \\
(\%)\end{array}$ & $\begin{array}{c}\text { Scoliotic } \\
\text { fish } \\
(\%)\end{array}$ \\
\hline 1 & 0 & Trp-free & 2.16 & $4 \cdot 1^{2 * 3}$ & $4.2^{\mathrm{a} * 3}$ & $3.35^{\mathrm{a} * 3}$ & $15.0^{\mathrm{a}}$ \\
\hline 2 & 0.05 & Basal diet (Trp-deficient) & 2.10 & $33.9^{b}$ & $29.2^{b}$ & $3.56^{\mathrm{a}}$ & $65.0^{\mathrm{b}}$ \\
\hline 3 & 0.05 & $+0.1 \mathrm{mg} \mathrm{5-HTP}$ & 2.05 & $32.8^{\mathrm{b}}$ & $28.4^{\mathrm{b}}$ & $3.54^{\mathrm{a}}$ & $61.7^{b}$ \\
\hline 4 & 0.05 & $+1 \mathrm{mg} 5$-HTP & 2.06 & $33.1^{\mathrm{b}}$ & $28.0^{\mathrm{b}}$ & $3.62^{\mathrm{a}}$ & $65.0^{\mathrm{b}}$ \\
\hline 5 & 0.05 & $+10 \mathrm{mg}$ 5-HTP & 2.05 & $34.2^{\mathrm{D}}$ & $29.7^{b}$ & $3.51^{\mathrm{s}}$ & $63.3^{\mathrm{b}}$ \\
\hline 6 & 0.05 & $+100 \mathrm{mg} 5-\mathrm{HTP}$ & 2.04 & $37.1^{\mathrm{b}}$ & $30.5^{b}$ & $3.66^{\mathrm{s}}$ & $1.7^{\mathrm{a}}$ \\
\hline 7 & 0.29 & $+240 \mathrm{mg}$ Trp (Trp-sufficient) & 2.07 & $102.9^{c}$ & $50.2^{\mathrm{c}}$ & $4.84^{b}$ & $0^{\mathrm{a}}$ \\
\hline \multicolumn{4}{|c|}{$\operatorname{SEM}(d f=7)$} & 1.86 & 0.80 & 0.174 & 4.41 \\
\hline
\end{tabular}

*1 Average value of duplicate tanks containing 30 fish each reared for 4 weeks at $15.0 \pm 0.6^{\circ} \mathrm{C}$.

*2. Expressed as (Wet weight gain/Dry feed intake) $\times 100$.

*3 Values with different superscripts in the same column are significantly different $(p<0.05)$. 
Table 3. Serotonin (5-HT), 5-hydroxyindoleacetic acid (5-HIAA), norepinephrine (NE) and dopamine (DA) contents in the whole brain of chum salmon fry fed test diets containing various level of L-tryptophan (Trp) and 5-hydroxy-L-tryptophan (5-HTP)

\begin{tabular}{|c|c|c|c|c|c|c|}
\hline $\begin{array}{c}\text { Diet } \\
\text { no. }\end{array}$ & $\begin{array}{l}\text { Trp \% } \\
\text { in diet }\end{array}$ & $\begin{array}{c}\text { Dietary } \\
\text { treatment }\end{array}$ & $\begin{array}{l}5-\mathrm{HT}^{* 1} \\
(\mathrm{ng} / \mathrm{g})^{* 3}\end{array}$ & $\underset{(\mathrm{ng} / \mathrm{g})^{* 3}}{5-\mathrm{HIAA}}$ & $\begin{array}{c}\mathrm{NE}^{* 2} \\
(\mathrm{ng} / \mathrm{g})^{* 3}\end{array}$ & $\begin{array}{c}\mathrm{DA}^{* 2} \\
(\mathrm{ng} / \mathrm{g})^{* 3}\end{array}$ \\
\hline 1 & 0 & Trp-free & $120^{\mathrm{ab} * 4}$ & $43.2^{b * 4}$ & $281^{\mathrm{d} * 4}$ & $179^{\mathrm{c} * \mathrm{i}}$ \\
\hline 2 & 0.05 & Basal diet (Trp-deficient) & $140^{\mathrm{bc}}$ & $31.0^{\mathrm{a}}$ & $183^{a}$ & $100^{\mathrm{a}}$ \\
\hline 3 & 0.05 & $+0.1 \mathrm{mg} \mathrm{5-HTP}$ & $140^{\mathrm{bc}}$ & $40.2^{b}$ & $205^{a b}$ & $147^{\mathrm{abc}}$ \\
\hline 4 & 0.05 & $+1 \mathrm{mg} 5$-HTP & $113^{a b}$ & $43.3^{b}$ & $178^{a}$ & $107^{a b}$ \\
\hline 5 & 0.05 & $+10 \mathrm{mg} 5$-HTP & $105^{a}$ & $38.8^{\mathrm{ab}}$ & $221^{\mathrm{b}}$ & $150^{\mathrm{abc}}$ \\
\hline 6 & 0.05 & $+100 \mathrm{mg}$ 5-HTP & $164^{\mathrm{ed}}$ & $78.4^{\mathrm{d}}$ & $237^{\mathrm{bc}}$ & $147^{a b c}$ \\
\hline 7 & 0.29 & $+240 \mathrm{mg}$ Trp (Trp-sufficient) & $177^{\mathrm{d}}$ & $55.1^{\mathrm{c}}$ & $270^{\mathrm{cd}}$ & $167^{b c}$ \\
\hline SEM & & $(d f=$ & $\begin{array}{c}14 \\
9.4\end{array}$ & $\begin{array}{c}14 \\
4.99\end{array}$ & $\begin{array}{l}21 \\
11.6\end{array}$ & $\left.\begin{array}{l}21 \\
20.1\end{array}\right)$ \\
\hline
\end{tabular}

*1 Average value of three pooled samples (5-8 fish/sample) from each group reared for 4 weeks at $15.0 \pm 0.6^{\circ} \mathrm{C}$.

*2 Average value of 4 fish from each group.

* $\mathrm{ng} / \mathrm{g}$ wet tissue.

*4 Values with different superscripts in the same column are significantly different $(p<0.05)$.

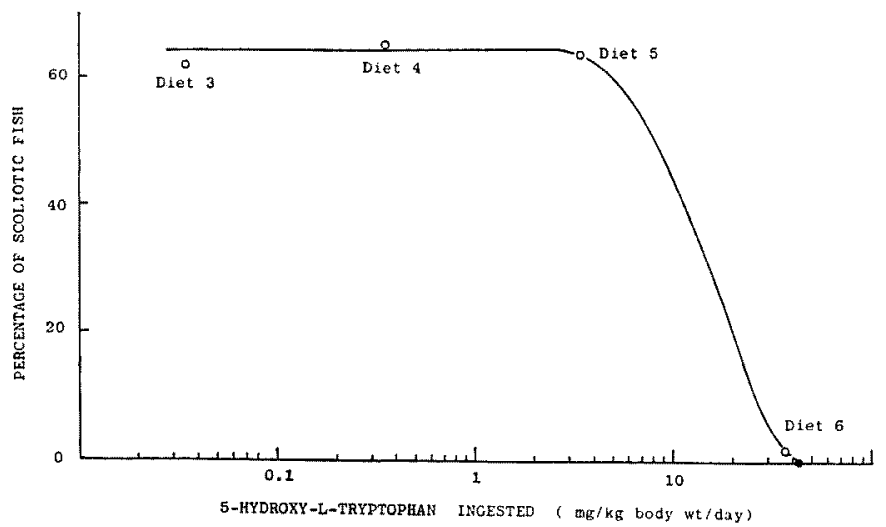

Fig. 1. The relationship between 5-hydroxy-L-tryptophan ingested and the incidence of scoliosis caused by tryptophan deficiency.

$\left(\bigcirc ;\right.$ the data in this study, $\bullet$; the datum in the previous paper $\left.{ }^{2)}\right)$

approached the value of the control group, as the dose of 5-HTP increased. Therefore, judging from incidence of scoliosis in the previous and present feeding trials and the amine levels in the brain, the minimum dose of 5-HTP for preventing the occurrence of scoliosis derived from Trp deficiency was estimated to be between 100-130 $\mathrm{mg}$ per $100 \mathrm{~g}$ diet. If expressed in the quantity ingested, it seemed to be approximately $40 \mathrm{mg} / \mathrm{kg}$ body weight/day as presented in Fig. 1.

The incidence of scoliosis of the group fed Trp-free diet was much lower than that of the group fed Trp-deficient diet. Even though any exogenous Trp was not supplied to the former group, the value was not significantly different from that of the control group fed the Trp-sufficient diet. This relationship between the amount of
Trp intake and the incidence of scoliosis has been reported also in Trp requiremental experiments of rainbow trout fed casein acid hydrolysate, gelatin and amino acids as nitrogen source ${ }^{3)}$ and coho salmon fed only amino acid mixture as nitrogen source. ${ }^{* 3}$ In this study, no significant difference in the brain 5-HT content was detected between these two groups, while 5-HIAA content of the fish fed Trp-free diet was slightly higher than that of Trp-deficient diet, suggesting that 5-HT metabolism in the former was slightly active compared with the latter. However, it is doubtful that this degree of difference in 5-HT metabolism had decisive influence on the occurrence of scoliosis. Both NE and DA contents of the fish fed Trp-free diet were much higher than those fed Trp-deficient diet, being rather close to those of 
Table 4. Free amino acid contents in the whole brain of chum salmon fry fed test diets containing various levels of tryptophan (Trp) and 5-hydroxy-L-tryptophan (5-HTP) for 4 weeks*1

\begin{tabular}{|c|c|c|c|c|c|c|c|}
\hline \multirow{4}{*}{$\begin{array}{c}\text { Amino acids } \\
\text { ( } \mu \text { mole/g wet tissue) }\end{array}$} & ${ }_{1}^{\text {Diet no. }}$ & 2 & 3 & 4 & 5 & 6 & 7 \\
\hline & Trp 0\% & \multicolumn{5}{|c|}{$\operatorname{Trp} 0.05 \%$} & \multirow[t]{3}{*}{$\operatorname{Trp} 0.29 \%$} \\
\hline & & \multicolumn{5}{|c|}{ 5-HTP (mg/100 g diet) } & \\
\hline & & 0 & 0.1 & 1.0 & 10 & 100 & \\
\hline Phosphoserine & $0.47^{b * 2}$ & $0.29^{a}$ & $0.43^{b}$ & $0.42^{b}$ & $0.45^{\mathrm{b}}$ & $0.44^{b}$ & $0.37^{\mathrm{ab}}$ \\
\hline Taurine & $16.92^{a b * 2}$ & $17.20^{\mathrm{b}}$ & $17.26^{b}$ & $17.29^{\circ}$ & $16.30^{\mathrm{a}}$ & $17.65^{b c}$ & $18.16^{\mathrm{c}}$ \\
\hline Phosphoethanolamine & $0.92^{\mathrm{c} * 2}$ & $0.82^{\mathrm{ab}}$ & $0.81^{\mathrm{a}}$ & $0.83^{\mathrm{abc}}$ & $0.81^{\mathrm{a}}$ & $0.92^{\mathrm{bc}}$ & $1.23^{\mathrm{d}}$ \\
\hline Aspartic acid & $1.41^{a * 2}$ & $1.48^{\mathrm{a}}$ & $1.35^{8}$ & $1.33^{\mathrm{a}}$ & $1.33^{\mathrm{a}}$ & $1.56^{\mathrm{sb}}$ & $1.78^{\mathrm{b}}$ \\
\hline Threonine & $0.42^{\mathrm{a} * 2}$ & $0.45^{\mathrm{a}}$ & $0.43^{\mathrm{a}}$ & $0.48^{\mathrm{a}}$ & $0.48^{\mathrm{a}}$ & $1.05^{b}$ & $0.49^{\mathrm{g}}$ \\
\hline Serine & $1.18^{b * 2}$ & $1.18^{b}$ & $1.16^{b}$ & $1.17^{\mathrm{b}}$ & $1.10^{b}$ & $1.13^{b}$ & $0.85^{\mathrm{a}}$ \\
\hline Glutamic acid & $6.32^{\mathrm{a} * 2}$ & $6.54^{\mathrm{ab}}$ & $6.51^{\mathrm{sb}}$ & $6.57^{\mathrm{ab}}$ & $6.20^{\mathrm{n}}$ & $6.94^{\mathrm{bo}}$ & $7.15^{\mathrm{e}}$ \\
\hline Glutamine & $7.68^{\mathrm{a} * 2}$ & $7.88^{\mathrm{a}}$ & $7.82^{\mathrm{a}}$ & $8.07^{\mathrm{a}}$ & $7.50^{\mathrm{z}}$ & $8.29^{\circ}$ & $7.51^{\mathrm{s}}$ \\
\hline Glycine & $2.06^{\mathrm{cd} * 2}$ & $1.97^{\mathrm{bcd}}$ & $1.96^{\mathrm{bc}}$ & $2.00^{\mathrm{bcd}}$ & $1.89^{b}$ & $2.08^{\mathrm{d}}$ & $1.58^{\mathrm{a}}$ \\
\hline Alanine & $0.58^{* * 2}$ & $0.60^{\mathrm{be}}$ & $0.68^{b c}$ & $0.73^{\mathrm{c}}$ & $0.70^{\mathrm{bc}}$ & $0.68^{b c}$ & $0.62^{2 b}$ \\
\hline Valine & $0.16^{\mathrm{a} * 2}$ & $0.10^{\mathrm{a}}$ & $0.13^{8}$ & $0.07^{a}$ & $0.15^{\mathrm{e}}$ & $0.08^{n}$ & $0.09^{\circ}$ \\
\hline Isoleucine & n.d. & n.d. & n.d. & n.d. & n.d. & n.d. & n.d. \\
\hline Leucine & n.d. & 0.07 & 0.07 & 0.06 & 0.06 & 0.08 & 0.09 \\
\hline Tyrosine & n.d. & n.d. & n.d. & n.d. & n.d. & n.d. & n.d. \\
\hline Phenylalanine & 0.11 & 0.11 & 0.11 & 0.12 & 0.11 & 0.11 & 0.10 \\
\hline$\gamma$-Amino-butyric acid & $3.46^{\mathrm{s} b * 2}$ & $3.35^{\mathrm{a}}$ & $3.37^{a}$ & $3.34^{\mathrm{a}}$ & $3.27^{\mathrm{a}}$ & $3.54^{\mathrm{ab}}$ & $3.75^{b}$ \\
\hline Ethanolamine & $0.34^{a * 2}$ & $0.30^{\mathrm{a}}$ & $0.36^{\mathrm{s}}$ & $0.37^{\mathrm{a}}$ & $0.37^{\AA}$ & $0.37^{\mathrm{B}}$ & $0.34^{\mathrm{a}}$ \\
\hline Tryptophan & n.d. & n.d. & n.d. & n.d. & 0.26 & 0.24 & n.d. \\
\hline $\mathrm{NH} 3$ & $2.83^{* 2}$ & $2.10^{\mathrm{a}}$ & $2.84^{\mathrm{a}}$ & $2.90^{\mathrm{a}}$ & $2.55^{\mathrm{a}}$ & $2.44^{\mathrm{a}}$ & $2.26^{\mathrm{a}}$ \\
\hline Ornithine & 0.27 & 0.23 & n.d. & 0.03 & 0.12 & n.d. & n.d. \\
\hline Lysine & $1.02^{b \star 2}$ & $1.39^{\mathrm{b}}$ & $1.09^{\mathrm{b}}$ & $1.10^{\mathrm{b}}$ & $1.36^{\mathrm{b}}$ & $0.94^{b}$ & $0.35^{\mathrm{a}}$ \\
\hline Histidine & $2.08^{a * 2}$ & $3.80^{\mathrm{c}}$ & $3.43^{\mathrm{bcc}}$ & $3.45 \mathrm{bc}$ & $3.68^{\mathrm{c}}$ & $2.63^{\mathrm{ab}}$ & $2.10^{\mathrm{a}}$ \\
\hline Carnosine & $3.64^{*} * 2$ & $3.64^{\mathrm{a}}$ & $3.93^{\mathrm{a}}$ & $3.62^{\mathrm{n}}$ & $3.42^{\mathrm{g}}$ & $3.58^{\mathrm{s}}$ & $4.83^{b}$ \\
\hline Arginine & n.d. & 0.05 & 0.04 & 0.06 & n.d. & 0.06 & 0.14 \\
\hline Proline & $0.25^{\mathrm{ab} * 2}$ & $0.39 a b c$ & $0.51^{b c}$ & $0.51^{b c}$ & $0.64^{c}$ & $0.40^{\mathrm{abc}}$ & $0.08^{\mathrm{a}}$ \\
\hline
\end{tabular}

*1 Average value of two pooled samples (6 fish/sample) from each group reared for 4 weeks at $15.0 \pm 0.6^{\circ} \mathrm{C}$.

*2 Values with different superscripts in the same column are significantly different $(P<0.05)$.

the control. It has been reported in rat that a torticollis or an abnormal attitude is induced by a destruction of tegmentum mescencephali in which DA neuron and 5-HT neuron are closely located. ${ }^{10}$ In man, a patient of parkinsonism whose symptoms are characterized by anteflexion attitude and slight scoliosis ${ }^{11}$ shows low level of brain catecholamine, especially DA. ${ }^{12)}$ Therefore, there might be a possibility that catecholamine level is also related to an occurrence of scoliosis caused by Trp deficiency. In addition, the facts that the dose of Trp in the diet ingested was not directly related to the brain catecholamine content and incidence of scoliosis suggest that there may be a considerable physiological difference between complete lack of Trp and an intake of low level of Trp; an insufficient supply of essential nutrient is likely to make physiological imbalance severer than the condition of complete absence.

Moreover, it became apparent that Trp levels in diet affected the metabolisms of not only indoleamine and catecholamine but also free amino acids in brain as shown in Table 4 . The brain contents of aspartic acid (Asp), glutamic acid (Glu) and gamma-amino-butyric acid (GABA) which are neurotransmitters ${ }^{13)}$ were low in the fish administrated no Trp (Diet 1) and a small quantity of Trp (Diets 2-5), but it seems that those values were increased by the administrations of $100 \mathrm{mg}$ 5-HTP $/ 100 \mathrm{~g}$ diet (Diet 6) or requisite level of Trp (Diet 7). Among taurine, serine, glycine and proline which are presumed to be neurotransmitters, ${ }^{12)}$ only taurine content increased together with Asp, Glu and GABA when fed Diets 6 and 7. On the other hand, serine, glycine and proline in the fish fed Diet 7 were apparently lower than those in the other dietary treatments. Thus, the brain levels of these amino acids described above seem to be influenced by brain 5-HT or dietary Trp. 


\section{Acknowledgements}

The authors are grateful to Hokkaido Salmon Hatchery for providing the chum salmon eggs and to the Ajinomoto Co., Ltd. for providing the crystalline amino acids.

\section{References}

1) T. Akiyama, T. Murai, and T. Nsoe: Nippon Suisan Gakkaishi, 52, 1249-1254 (1986).

2) T. Akiyama, T. Murai, and K. Mori: Nippon Suisan Gakkaishi, 52, 1255-1259 (1986).

3) H. A. Poston and G. L. Rumsey: J. Nutr., 113, 2568-2577 (1983).

4) National Research Council: National Academy of Science, Washington, D. C., 1973, pp. 57.

5) J. E. Halver: J. Nutr, 62, 225-243 (1957).
6) T. Akiyama, S. Arai, T. Murai, and T. Nose: Nippon Suisan Gakkaishi, 51, 1005-1008 (1985).

7) T. Akiyama, S. Arai. T. Murai, and T. Nose: Nippon Suisan Gakkaishi, 51, 635-639 (1985).

8) G. Curzon and A. R. Green: Br.J. Pharmacol,, 39, 653-655 (1970).

9) D. B. Duncan: Biometrics, 11, 1-42 (1955).

10) C. Tanaka and M. Kimura: in "Neurotransmitters" (ed. by G. Takagaki and T. Nagatsu), Koudansha, Tokyo, 1984, pp. 156-191.

11) T. Hattori: in "Spinal Deformities" (ed. by K. Yamada and S. Inoue), Igakushoin, Tokyo, 1979, pp. 78-87.

12) T. Nagatsu: Protein, Nucleic acid and Enzyme, 26, 1781-1788 (1981).

13) T. Nagatsu: Metabolism and Disease, 25, 574580 (1988). 